\title{
Development of a Real-Time, Quantitative PCR for Detection of the Columbia Basin Potato Purple Top Phytoplasma in Plants and Beet Leafhoppers
}

\author{
J. M. Crosslin and G. J. Vandemark, USDA-ARS, Vegetable and Forage Crops Research Unit, Prosser, WA 99350; \\ and J. E. Munyaneza, USDA-ARS, Yakima Agricultural Research Laboratory, Wapato, WA 98951
}

\begin{abstract}
Crosslin, J. M., Vandemark, G. J., and Munyaneza, J. E. 2006. Development of a real-time, quantitative PCR for detection of the Columbia Basin potato purple top phytoplasma in plants and beet leafhoppers. Plant Dis. 90:663-667.

A quantitative, real-time "TaqMan" polymerase chain reaction assay (real-time PCR) was developed which was capable of detecting and quantifying a group 16SrVI phytoplasma in DNA extracts prepared from infected tomatoes, potatoes, and beet leafhoppers (Circulifer tenellus). Primers and probe were designed from the 16S rRNA gene of the Columbia Basin potato purple top phytoplasma, which is closely related to the beet leafhopper transmitted virescence agent. The detection limit in phytoplasma-infected tomato DNA was approximately $50 \mathrm{pg}$. The concentration of phytoplasma varied considerably among potato plants showing symptoms of purple top. The pathogen was readily detected in extracts from single or groups of five beet leafhoppers. As with infected potatoes, the concentration of phytoplasma in individual leafhoppers was variable. The assay also detected aster yellows (group 16SrI) and pigeon pea witches'-broom (group 16SrIX) phytoplasmas in infected periwinkle plants. The real-time PCR was at least as sensitive as the commonly used and more labor-intensive nested PCR for detection of the pathogen.
\end{abstract}

Additional keywords: insect vectors

Phytoplasmas, previously called mycoplasmalike organisms, $(6,38)$ are wallless prokaryotes of the class Mollicutes. These organisms are the causal agents of numerous plant diseases including aster yellows (AY), western X-disease, alfalfa witches'-broom, potato witches'-broom, apple proliferation, pigeon pea witches'broom (PPWB), clover proliferation (CP), and many others $(12,21,23,29)$. The phytoplasmas are transmitted by several species of insects, particularly leafhoppers (Cicadellidae) and psyllids (Psyllidae) (6). The aster leafhopper (Macrosteles fascifrons Stål) transmits the aster yellows phytoplasma, which has a broad host range (29). Another common insect, the beet leafhopper (Circulifer tenellus Baker), transmits the vinca virescence or beet leafhopper-transmitted virescence agent (BLTVA) $(14,35)$. Numerous other vector species of different phytoplasmas have been identified (29).

Previous research has shown that BLTVA infects a number of agriculturally important plants (14). This organism was

Corresponding author: J. M. Crosslin

E-mail: jcrosslin@pars.ars.usda.gov

Accepted for publication 4 January 2006.

DOI: 10.1094/PD-90-0663

This article is in the public domain and not copyrightable. It may be freely reprinted with customary crediting of the source. The American Phytopathological Society, 2006. identified as an important pathogen of radish seed crops in Washington (39) and Idaho (40), tomatoes in California (41), and potatoes in Utah (43). Recently, BLTVA has been implicated as the causal agent of the potato purple top and dry bean phyllody diseases in the Columbia Basin region of Washington and Oregon $(25,26)$. The Columbia Basin potato purple top phytoplasma, which is closely related to or synonymous with BLTVA, has been frequently detected within the beet leafhopper and occasionally within Ceratagallia spp. leafhoppers, but has not been detected in numerous insects of other cicadellid and delphacid taxa in Washington and Oregon (9). Recently, the purple top phytoplasma has been transmitted by the beet leafhopper from radishes to potatoes in greenhouse trials (J. E. Munyaneza and J. M. Crosslin, unpublished).

The phytoplasmas, in contrast to spiroplasmas, have not been successfully cultured in vitro $(6,29)$. Therefore, other methods have been devised for their study. These include serology $(8,11)$, use of labeled DNA hybridization probes $(10,13$, $27,28)$, and more recently the polymerase chain reaction (PCR) $(5,12,30,31,42)$. Gundersen and Lee (16) described a more sensitive nested PCR procedure, in which a portion of the first round reaction was removed, diluted, and used in a second PCR with primers internal to the first pair.

The advent of PCR and rapid cloning and sequencing technologies has allowed accumulation of genomic sequence infor- mation on the phytoplasmas, particularly the 16S rRNA genes and the 16S-23S intergenic spacer region. This information has led to phylogenetic separation of the phytoplasmas into groups, designated by $16 \mathrm{Sr}$ and Roman numerals from I to XIV. For example, the aster yellows group is $16 \mathrm{SrI}$ and the clover proliferation group (18), which includes BLTVA, comprises group 16SrVI (30).

The most recent innovation in the detection of phytoplasmas is the real-time, quantitative PCR (real-time PCR) methodology $(2,7,20,33)$. The real-time PCR can be completed more quickly than the nested PCR procedures. Real-time PCR reduces the chances of contamination since the reaction vessels do not need to be opened between the first round and nested reactions, and it also eliminates the need to analyze the reaction products by gel electrophoresis. The goal of the research described herein was the development of a real-time PCR for group 16SrVI phytoplasma in potatoes, tomatoes, and beet leafhopper vectors that would eliminate the need to use nested PCR.

\section{MATERIALS AND METHODS}

Plant materials and insects. Potatoes (Solanum tuberosum L.) showing symptoms of purple top disease were obtained from commercial potato fields and research plots in the Columbia Basin region of southern Washington and northern Oregon in middle to late summer. Most potato samples were cultivars Ranger Russet or Russet Burbank. Symptomatic shoots of selected plants were tip-grafted onto tomatoes (Lycopersicon esculentum Mill.) in the greenhouse. Symptoms on field-grown potato included stunting, leaf rolling, chlorosis, and purple discoloration of the leaflets. Some infected potatoes produced aerial tubers. The foliar symptoms on infected tomatoes consisted of shortened internodes, bunchy growth, purple discolorations, and reduced flowering typical of "big bud" symptoms (41). Periwinkle ( $\mathrm{Ca}$ tharanthus roseus (L.) G. Don) tissues infected with aster yellows and pigeon pea witches'-broom phytoplasmas were obtained from N. Harrison, University of Florida, Fort Lauderdale, and grafted onto healthy periwinkle plants maintained in a greenhouse. Symptoms included flower virescence, stunting, chlorosis, and mottling of leaves. Insects in and near potato fields were collected with sweep nets and 
identified at the Yakima Agricultural Research Laboratory (9). Insects identified as beet leafhoppers were stored in $70 \%$ ethanol at room temperature until used for nucleic acid extraction.

Nucleic acid extractions from plants and insects. Midveins, petioles, and small stem pieces of potato, tomato, and periwinkle were excised (approximately 200 to $500 \mathrm{mg}$ per sample) with a new razor blade and placed into a mesh grinding bag ( $\mathrm{Ag}$ dia, Inc., Elkhart, IN). Total nucleic acid et al. (36), with minor modifications. The tissue was triturated with $1.2 \mathrm{ml}$ of buffer (100 mM Tris- $\mathrm{HCl}, \mathrm{pH} 8.0,500 \mathrm{mM} \mathrm{NaCl}$, $50 \mathrm{mM}$ disodium ethylenediamine tetraacetic acid, $10 \mathrm{mM}$ 2-mercaptoethanol) using a large pestle. Six hundred microliters of the solution was placed in a microcentrifuge tube containing $60 \mu \mathrm{l}$ of $10 \%$ sodium dodecyl sulfate, mixed, and incubated $10 \mathrm{~min}$ at $65^{\circ} \mathrm{C}$. Two hundred microliters of acidified $5 \mathrm{M}$ potassium acetate (37) was then added, mixed by vortexing, and the solution incubated on ice $10 \mathrm{~min}$. Debris for $10 \mathrm{~min}$, and $600 \mu \mathrm{l}$ of the clarified supernatant was transferred to a new microcentrifuge tube. After addition of $300 \mu \mathrm{l}$ of isopropanol, the solution was mixed, held on ice $10 \mathrm{~min}$, and centrifuged for $10 \mathrm{~min}$. The nucleic acid pellet was washed once was extracted using the method of Presting was pelleted by centrifugation at $14,000 \times g$

with $70 \%$ ethanol, air-dried, and resuspended in $300 \mu$ of sterile distilled water.

Nucleic acids were extracted from insects using the CTAB extraction method of Zhang et al. (45) but without grinding in liquid nitrogen. Briefly, the insects (individually or in groups of five) were washed once with CTAB buffer, then ground in $600 \mu \mathrm{l}$ of fresh buffer using a micropestle, and processed as described. Nucleic acids were resuspended in $50 \mu \mathrm{l}$ of sterile distilled water for single insect extractions or in $100 \mu \mathrm{l}$ for the five insect extractions. In some tests, insects were extracted using the procedure described above for plant tissue, except the insects were ground in a $1.5-\mathrm{ml}$ microcentrifuge tube with a micropestle. Additional extracts were prepared from plants or insects using the FastDNA procedure as described by the manufacturer (Bio 101, Inc., Carlsbad, CA).

The DNA or total nucleic acid extracts were quantified using the double-stranded DNA specific reagent Picogreen (Invitrogen, Carlsbad, CA) and a fluorometer (Turner Designs, Inc., Sunnyvale, CA) as recommended by the manufacturers. The DNA concentrations of stock solutions were adjusted to 5 to $50 \mathrm{ng} / \mu \mathrm{l}$. Tenfold dilution series of some quantified DNA extracts were prepared in sterile distilled water for use in determining dilution endpoints and preparation of standard curves.

Table 1. Oligonucleotide primers and TaqMan probe sequences used for nested and real-time quantitative polymerase chain reaction (PCR) of phytoplasma in plants and insects

\begin{tabular}{lll}
\hline Primer or probe & Sequence $\left(\mathbf{5}^{\prime}\right.$ to $\left.\mathbf{3}^{\prime}\right)$ & Reference \\
\hline 16Sp303F & agggcctatagctcagttggttaga & This paper \\
16Sp378R & gtgggcctaatggacttgaac & This paper \\
Probe 16TM329 & 6Fam-cacacgcctgataagcgtgaggtcg-Tamra & This paper \\
P1 & aagagtttgatcctggctcaggatt & 13 \\
P7 & cgtccttcatcggctctt & 38 \\
fU5 & cggcaatggaggaaact & 34 \\
rU3 & ttcagctaccctttgtaaca & 34 \\
BLTVA-int & gatgatttagtatatatagtcc & 42 \\
\hline
\end{tabular}

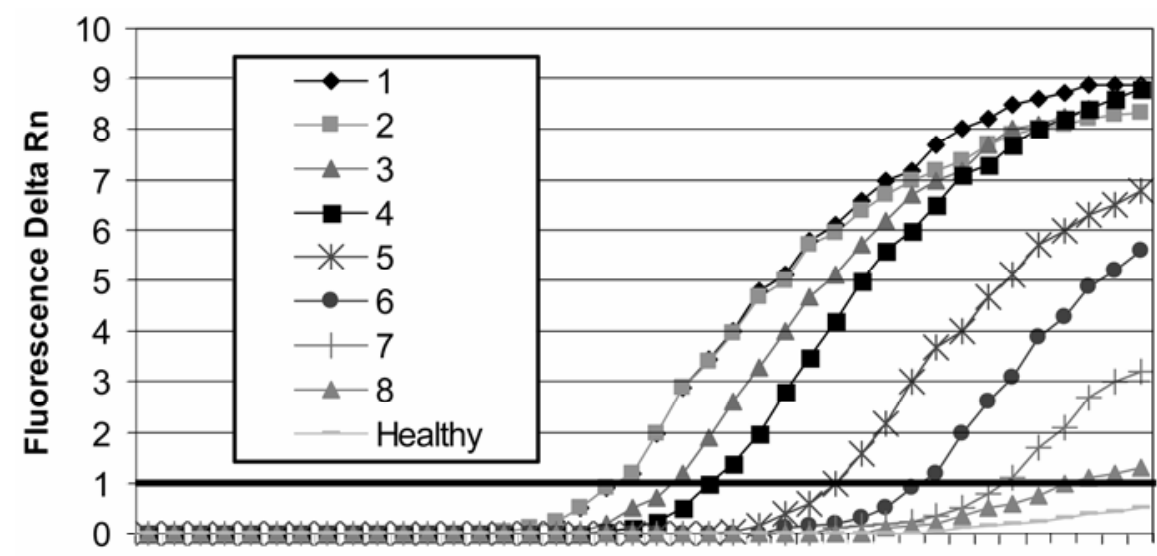

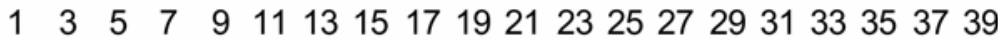

\section{Cycle Number}

Fig. 1. Real-time polymerase chain reaction (PCR) on $25 \mathrm{ng}$ of DNA from foliage of eight potato plants showing symptoms of purple top that were positive for phytoplasma by nested PCR, and a healthy 'Shepody' potato $\left(R^{2}=0.994\right.$, slope -3.65 , threshold 1.0$)$.
Design of real-time PCR primers and probes. The DNA sequence of a portion of the $16 \mathrm{~S}$ rRNA gene of the Columbia Basin potato purple top phytoplasma (GenBank accession AY692280; 9) was evaluated using the Primer Express software (Applied Biosystems, Inc. [ABI], Foster City, CA). Candidate primer and probe sequences were tested for homology to phytoplasma and other prokaryotic sequences using BLAST (1). Primers 16Sp303F, 16Sp378R, and TaqMan probe 16TM329 (Table 1) were selected because they showed homology to several phytoplasma sequences and little homology with other prokaryotic 16S rRNA genes. Primers $16 \mathrm{Sr} 303 \mathrm{~F}$ and $16 \mathrm{Sr} 378 \mathrm{R}$ amplify a 75 -bp segment corresponding to nucleotides 1611 to 1686 of AY692280. The probe was synthesized and labeled with 6-carboxyfluorescein (6-FAM) and tetra-methylcarboxyrhodamine (TAMRA) by ABI. Primers used for standard PCR reactions and realtime PCR (Table 1) were obtained from Sigma-Genosys (The Woodlands, TX).

PCR and real-time PCR. First-round reactions of nested PCR (16) utilized phytoplasma universal primers P1 and P7 (Table 1). Reaction mixtures contained $5 \mu \mathrm{l}$ of 10× PCR buffer (Promega, Madison, WI), $0.5 \mu \mathrm{l}$ of $10 \mathrm{mM}$ (each) dNTP mixture, $1 \mu \mathrm{l}$ each $20 \mu \mathrm{M}$ primer solution, $37.3 \mu \mathrm{l}$ of sterile distilled water, and $0.2 \mu \mathrm{l}(1 \mathrm{U})$ of $\mathrm{Taq}$ polymerase (Promega). Five microliters of DNA extracts varying in concentration were added; the reactions were overlaid with mineral oil and incubated $2 \mathrm{~min}$ at $94^{\circ} \mathrm{C}$, then 30 cycles of $94^{\circ} \mathrm{C}$ for $15 \mathrm{~s}, 55^{\circ} \mathrm{C}$ for 90 $\mathrm{s}, 72^{\circ} \mathrm{C}$ for $90 \mathrm{~s}$, followed by a final extension of $5 \mathrm{~min}$ at $72^{\circ} \mathrm{C}$, then held at $4{ }^{\circ} \mathrm{C}$. For the nested reaction, $5 \mu \mathrm{l}$ of the $\mathrm{P} 1 / \mathrm{P} 7$ reaction was removed, diluted with $95 \mu \mathrm{l}$ of sterile distilled water, and $2 \mu \mathrm{l}$ was used in reactions as above, except $5 \mu$ l of Rediload (Invitrogen) and primers fU5/BLTVA-int (Table 1) were included in the reaction mix and the amount of water was adjusted as necessary. The nested primer pair fU5/ BLTVA-int specifically amplifies group 16SrVI phytoplasmas $(9,42)$. For phytoplasma group-nonspecific amplification, the nested primers were fU5/rU3 (34). Amplification conditions were as described above. Ten microliters of the reactions were subjected to electrophoresis in $1.5 \%$ agarose gels, stained with ethidium bromide, and visualized with UV light (37). The fU5/ BLTVA-int and fU5/rU3 amplicons are approximately 1,200 and $880 \mathrm{bp}$, respectively.

Real-time PCR reactions were performed in Optical Tubes (ABI). The 50- $\mu$ l reactions consisted of $25 \mu \mathrm{l}$ of $2 \times$ TaqMan Universal PCR master mix (ABI), $900 \mathrm{nM}$ each primer (16Sp303F and 16Sp378R), $250 \mathrm{nM}$ probe 16TM329, sterile distilled water to $45 \mu \mathrm{l}$, and $5 \mu \mathrm{l}$ of the DNA sample. Most test reactions contained $25 \mathrm{ng}$ of DNA and were tested in duplicate or triplicate. Because of the low yield of DNA from some insect samples, these were 
often tested singly. DNA samples were diluted 10-fold in water and tested in triplicate for development of standard curves using BLTVA-infected tomato DNA. Realtime PCR was conducted on an ABI 7000 instrument with the default parameters $\left(50^{\circ} \mathrm{C}\right.$ for $2 \mathrm{~min}, 95^{\circ} \mathrm{C}$ for $10 \mathrm{~min}, 40 \mathrm{cy}-$ cles of $95^{\circ} \mathrm{C}$ for $15 \mathrm{~s}$, and $60^{\circ} \mathrm{C}$ for $1 \mathrm{~min}$ ).

Data analysis. After real-time PCR reactions were completed, threshold values were adjusted to 1.0 to enable comparison of data sets. Standard curves were computed using triplicate wells of BLTVA-infected tomato DNA in 10-fold dilutions from $500 \mathrm{ng}$ to $0.005 \mathrm{ng}$ per well. The mean threshold cycle $(\mathrm{Ct})$ values were calculated as were standard deviation among the replicates. Quantity calculations in potato and insect samples were based upon the infected tomato DNA standard curve.

\section{RESULTS AND DISCUSSION}

The real-time PCR assay reliably detected the group 16SrVI phytoplasma in
DNA from infected tomatoes, potatoes, and the aster yellows (group 16SrI) and pigeon pea witches'-broom (group 16SrIX) phytoplasma-infected periwinkles (Table $2)$. The dilution endpoint in DNA from infected tomatoes was 5 to $50 \mathrm{pg}$ by realtime PCR, and nested PCR detected phytoplasma in $500 \mathrm{pg}$ but not $50 \mathrm{pg}$ of DNA from the infected tomato (Table 2). A dilution series of $5 \mathrm{pg}$ to $50 \mathrm{ng}$ of DNA from six potato plants showing symptoms of purple top indicated that there was consid-

Table 2. Real-time polymerase chain reaction (PCR) and nested PCR results on healthy and beet leafhopper-transmitted virescence agent (BLTVA)-infected tomato, aster yellows (AY), and pigeon pea witches'-broom (PPWB)-infected periwinkles, and six potato plants showing symptoms of potato purple top ( ${ }^{2}$ 0.9988 , slope -3.42 , intercept 31.67 , threshold 1.0$)^{\mathrm{a}}$

\begin{tabular}{|c|c|c|c|c|c|c|}
\hline Sample & $\begin{array}{c}\text { DNA } \\
\text { concentration }\end{array}$ & Replications & Std. Dev. & $\mathbf{C} \mathbf{t}^{\mathbf{b}}$ & Quantity $^{\mathrm{c}}$ & $\begin{array}{l}\text { Nested } \\
\text { PCR }^{\text {d }}\end{array}$ \\
\hline BLTVA-infected tomato & $\begin{array}{r}500 \mathrm{ng} \\
50 \mathrm{ng} \\
5 \mathrm{ng} \\
500 \mathrm{pg} \\
50 \mathrm{pg} \\
5 \mathrm{pg}\end{array}$ & $\begin{array}{l}3 \\
3 \\
3 \\
3 \\
3 \\
3\end{array}$ & $\begin{array}{l}0.037 \\
0.004 \\
0.057 \\
0.035 \\
0.089 \\
0.151\end{array}$ & $\begin{array}{l}22.53 \\
25.85 \\
29.11 \\
32.60 \\
36.47 \\
39.40\end{array}$ & $\begin{array}{c}500 \\
50 \\
5 \\
0.5 \\
0.05 \\
0.005\end{array}$ & $\begin{array}{l}+ \\
+ \\
+ \\
+ \\
- \\
-\end{array}$ \\
\hline Healthy tomato & $50 \mathrm{ng}$ & 3 & 0.000 & $--\mathrm{e}$ & -- & - \\
\hline AY-infected periwinkle & $\begin{array}{r}50 \mathrm{ng} \\
5 \mathrm{ng} \\
500 \mathrm{pg}\end{array}$ & $\begin{array}{l}1 \\
1 \\
1\end{array}$ & $\begin{array}{l}-- \\
-- \\
--\end{array}$ & $\begin{array}{l}19.74 \\
23.00 \\
26.17\end{array}$ & $\begin{array}{r}3068.70 \\
343.02 \\
40.48\end{array}$ & $\begin{array}{l}-\mathrm{f} \\
- \\
-\end{array}$ \\
\hline PPWB-infected periwinkle & $\begin{array}{r}50 \mathrm{ng} \\
5 \mathrm{ng} \\
500 \mathrm{pg}\end{array}$ & $\begin{array}{l}1 \\
1 \\
1\end{array}$ & $\begin{array}{l}-- \\
-- \\
--\end{array}$ & $\begin{array}{l}30.98 \\
34.35 \\
37.03\end{array}$ & $\begin{array}{l}1.59 \\
0.17 \\
0.03\end{array}$ & $\begin{array}{l}- \\
- \\
-\end{array}$ \\
\hline Healthy periwinkle & $\begin{array}{r}50 \mathrm{ng} \\
5 \mathrm{ng} \\
500 \mathrm{pg}\end{array}$ & $\begin{array}{l}1 \\
1 \\
1\end{array}$ & $\begin{array}{l}-- \\
-- \\
--\end{array}$ & $\begin{array}{l}-- \\
-- \\
--\end{array}$ & $\begin{array}{l}-- \\
-- \\
--\end{array}$ & $\begin{array}{l}- \\
- \\
-\end{array}$ \\
\hline Symptomatic potato A & $\begin{array}{r}50 \mathrm{ng} \\
5 \mathrm{ng} \\
500 \mathrm{pg} \\
50 \mathrm{pg} \\
5 \mathrm{pg}\end{array}$ & $\begin{array}{l}2 \\
2 \\
2 \\
2 \\
2\end{array}$ & $\begin{array}{c}0.058 \\
0.139 \\
0.302 \\
-- \\
--\end{array}$ & $\begin{array}{l}31.16 \\
34.30 \\
37.62 \\
-- \\
--\end{array}$ & $\begin{array}{l}1.45 \\
0.17 \\
0.02 \\
-- \\
--\end{array}$ & $\begin{array}{l}+ \\
+ \\
- \\
- \\
-\end{array}$ \\
\hline Symptomatic potato B & $\begin{array}{r}50 \mathrm{ng} \\
5 \mathrm{ng} \\
500 \mathrm{pg} \\
50 \mathrm{pg} \\
5 \mathrm{pg}\end{array}$ & $\begin{array}{l}2 \\
2 \\
2 \\
2 \\
2\end{array}$ & $\begin{array}{c}0.495 \\
0.251 \\
-- \\
-- \\
--\end{array}$ & $\begin{array}{l}35.75 \\
38.00 \\
-- \\
-- \\
--\end{array}$ & $\begin{array}{l}0.66 \\
0.14 \\
-- \\
-- \\
--\end{array}$ & $\begin{array}{l}+ \\
+ \\
- \\
- \\
-\end{array}$ \\
\hline Symptomatic potato $\mathrm{C}$ & $\begin{array}{r}50 \mathrm{ng} \\
5 \mathrm{ng} \\
500 \mathrm{pg} \\
50 \mathrm{pg} \\
5 \mathrm{pg}\end{array}$ & $\begin{array}{l}2 \\
2 \\
2 \\
2 \\
2\end{array}$ & $\begin{array}{l}0.000 \\
0.047 \\
0.067 \\
0.021 \\
0.089\end{array}$ & $\begin{array}{l}22.55 \\
26.03 \\
29.56 \\
33.00 \\
36.36\end{array}$ & $\begin{array}{r}463.95 \\
44.43 \\
4.15 \\
0.41 \\
0.04\end{array}$ & $\begin{array}{l}+ \\
+ \\
+ \\
+ \\
-\end{array}$ \\
\hline Symptomatic potato D & $\begin{array}{r}50 \mathrm{ng} \\
5 \mathrm{ng} \\
500 \mathrm{pg} \\
50 \mathrm{pg} \\
5 \mathrm{pg}\end{array}$ & $\begin{array}{l}2 \\
2 \\
2 \\
2 \\
2\end{array}$ & $\begin{array}{l}0.054 \\
0.102 \\
0.006 \\
0.053 \\
0.039\end{array}$ & $\begin{array}{l}21.24 \\
24.55 \\
28.07 \\
31.63 \\
35.08\end{array}$ & $\begin{array}{r}1122.22 \\
121.11 \\
11.33 \\
1.02 \\
0.10\end{array}$ & $\begin{array}{l}+ \\
+ \\
+ \\
+ \\
+\end{array}$ \\
\hline Symptomatic potato E & $\begin{array}{r}50 \mathrm{ng} \\
5 \mathrm{ng} \\
500 \mathrm{pg} \\
50 \mathrm{pg} \\
5 \mathrm{pg}\end{array}$ & $\begin{array}{l}2 \\
2 \\
2 \\
2 \\
2\end{array}$ & $\begin{array}{c}0.010 \\
0.175 \\
-- \\
-- \\
--\end{array}$ & $\begin{array}{l}34.10 \\
37.20 \\
-- \\
-- \\
--\end{array}$ & $\begin{array}{l}0.20 \\
0.02 \\
-- \\
-- \\
--\end{array}$ & $\begin{array}{l}+ \\
+ \\
- \\
- \\
-\end{array}$ \\
\hline Symptomatic potato $\mathrm{G}$ & $\begin{array}{r}50 \mathrm{ng} \\
5 \mathrm{ng} \\
500 \mathrm{pg} \\
50 \mathrm{pg} \\
5 \mathrm{pg}\end{array}$ & $\begin{array}{l}2 \\
2 \\
2 \\
2 \\
2\end{array}$ & $\begin{array}{l}0.025 \\
0.022 \\
0.145 \\
0.016 \\
0.009\end{array}$ & $\begin{array}{l}19.25 \\
22.73 \\
25.94 \\
29.40 \\
33.10\end{array}$ & $\begin{array}{r}4280.44 \\
409.99 \\
47.51 \\
4.60 \\
0.38\end{array}$ & $\begin{array}{l}+ \\
+ \\
+ \\
+ \\
-\end{array}$ \\
\hline
\end{tabular}

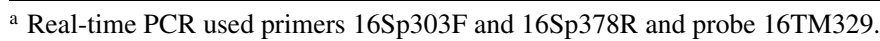

b Threshold cycle.

${ }^{\mathrm{c}}$ Quantity is expressed as ng of phytoplasma-infected tomato DNA.

${ }^{\mathrm{d}}$ Primers were P1/P7//fU5/BLTVA-int. (+) and (-) indicate that the expected band was present or absent, respectively, after agarose gel electrophoresis.

e Not detected.

${ }^{\mathrm{f}} \mathrm{AY}$ and PPWB phytoplasmas are not amplified with the group 16SrVI-specific nested PCR primers, fU5/BLTVA-int. 
erable variability in the amount of phytoplasma DNA in these plants (Table 2). This result was confirmed when $25 \mathrm{ng}$ of DNA from eight purple top-symptomatic plants were tested and the threshold cycle values (Ct) were plotted (Fig. 1). The data illustrated in Figure 1 and Table 2 correlate to a several thousand-fold difference in phyto- plasma DNA concentration among the extracts from the purple top-symptomatic potato plants.

The phytoplasma was also detected by real-time PCR in individual and five-insect groups of beet leafhoppers (Table 3). The quantity of phytoplasma DNA, expressed as nanograms of infected tomato DNA,

Table 3. Real-time polymerase chain reaction (PCR) results with individual and groups of five beet leafhoppers $\left(\mathrm{R}^{2} 0.997441 \text {, slope }-3.388 \text {, threshold } 1.0\right)^{\mathrm{a}}$

\begin{tabular}{|c|c|c|c|c|}
\hline Sample & $\begin{array}{c}\text { DNA } \\
\text { concentration }\end{array}$ & $\mathbf{C t}^{\mathbf{b}}$ & Quantity $^{c}$ & $\begin{array}{l}\text { Nested } \\
\text { PCR }^{\text {d }}\end{array}$ \\
\hline BLTVA-infected tomato $\mathrm{e}$ & $50 \mathrm{ng}$ & 26.02 & 50 & + \\
\hline Healthy tomato ${ }^{\mathrm{f}}$ & $50 \mathrm{ng}$ & $--\mathrm{g}$ & -- & _- \\
\hline \multirow[t]{5}{*}{ Infected 5 beet leafhoppers ${ }^{h}$} & $50 \mathrm{ng}$ & 26.80 & 28.37 & + \\
\hline & $5 \mathrm{ng}$ & 30.23 & 2.76 & + \\
\hline & $500 \mathrm{pg}$ & 33.52 & 0.29 & + \\
\hline & $50 \mathrm{pg}$ & 37.38 & 0.02 & - \\
\hline & $5 \mathrm{pg}$ & -- & -- & - \\
\hline \multicolumn{5}{|l|}{ Unknown 5 beet leafhoppers $\mathrm{i}$} \\
\hline 1 & $25 \mathrm{ng}$ & 36.58 & 0.04 & - \\
\hline 2 & $25 \mathrm{ng}$ & 29.45 & 4.68 & + \\
\hline 3 & $25 \mathrm{ng}$ & 30.05 & 3.12 & + \\
\hline 4 & $25 \mathrm{ng}$ & -- & -- & - \\
\hline 5 & $25 \mathrm{ng}$ & -- & -- & - \\
\hline 6 & $25 \mathrm{ng}$ & -- & -- & - \\
\hline 7 & $25 \mathrm{ng}$ & 30.06 & 3.10 & + \\
\hline 8 & $25 \mathrm{ng}$ & 30.64 & 2.09 & + \\
\hline 9 & $25 \mathrm{ng}$ & 31.14 & 1.48 & + \\
\hline 10 & $25 \mathrm{ng}$ & 30.56 & 2.20 & + \\
\hline 11 & $25 \mathrm{ng}$ & 28.94 & 6.61 & + \\
\hline 12 & $25 \mathrm{ng}$ & 28.85 & 7.03 & + \\
\hline 13 & $25 \mathrm{ng}$ & -- & -- & - \\
\hline 14 & $25 \mathrm{ng}$ & -- & -- & - \\
\hline 15 & $25 \mathrm{ng}$ & -- & -- & - \\
\hline 16 & $25 \mathrm{ng}$ & 30.52 & 2.26 & + \\
\hline 17 & $25 \mathrm{ng}$ & 35.62 & 0.07 & + \\
\hline 18 & $25 \mathrm{ng}$ & -- & -- & - \\
\hline 19 & $25 \mathrm{ng}$ & 24.41 & 144.60 & + \\
\hline 20 & $25 \mathrm{ng}$ & 28.24 & 10.71 & + \\
\hline 21 & $25 \mathrm{ng}$ & -- & -- & - \\
\hline 22 & $25 \mathrm{ng}$ & 29.16 & 5.71 & + \\
\hline 23 & $25 \mathrm{ng}$ & -- & -- & - \\
\hline \multicolumn{5}{|c|}{ Unknown single beet leafhopper samples } \\
\hline 1 & $25 \mathrm{ng}$ & 28.62 & 8.24 & + \\
\hline 2 & $25 \mathrm{ng}$ & 39.15 & 0.01 & - \\
\hline 3 & $25 \mathrm{ng}$ & 30.91 & 1.74 & + \\
\hline 4 & $25 \mathrm{ng}$ & 30.97 & 1.67 & + \\
\hline 5 & $25 \mathrm{ng}$ & -- & -- & - \\
\hline 6 & $25 \mathrm{ng}$ & -- & -- & - \\
\hline 7 & $25 \mathrm{ng}$ & -- & -- & - \\
\hline 8 & $25 \mathrm{ng}$ & -- & -- & - \\
\hline 9 & $25 \mathrm{ng}$ & -- & -- & - \\
\hline 10 & $25 \mathrm{ng}$ & -- & -- & _- \\
\hline 11 & $25 \mathrm{ng}$ & -- & -- & - \\
\hline 12 & $25 \mathrm{ng}$ & 35.12 & 0.10 & + \\
\hline 13 & $25 \mathrm{ng}$ & 28.01 & 12.49 & + \\
\hline 14 & $25 \mathrm{ng}$ & -- & -- & + \\
\hline 15 & $25 \mathrm{ng}$ & -- & -- & - \\
\hline 16 & $25 \mathrm{ng}$ & -- & -- & - \\
\hline 17 & $25 \mathrm{ng}$ & -- & -- & - \\
\hline 18 & $25 \mathrm{ng}$ & -- & -- & - \\
\hline 19 & $25 \mathrm{ng}$ & -- & -- & - \\
\hline 20 & $25 \mathrm{ng}$ & -- & -- & - \\
\hline
\end{tabular}

${ }^{\text {a }}$ Real-time PCR used primers 16Sp303F and 16Sp378R and probe 16TM329.

b Threshold cycle.

${ }^{c}$ Quantity is expressed as ng of phytoplasma-infected tomato DNA.

${ }^{\mathrm{d}}$ Nested PCR primers were P1/P7//fU5/BLTVA-int. (+) and (-) indicate that the expected band was present or absent, respectively, after agarose gel electrophoresis.

${ }^{\mathrm{e}}$ Beet leafhopper-transmitted virescence agent. Tested in triplicate. $\mathrm{SD}=0.035$.

${ }^{\mathrm{f}}$ Tested in triplicate. $\mathrm{SD}=\mathrm{N} / \mathrm{A}$.

g Not detected.

${ }^{\mathrm{h}}$ Tested in duplicate. $\mathrm{SD}=0.000,0.130,0.077,0.018$, and N/A for $50 \mathrm{ng}, 5 \mathrm{ng}, 500 \mathrm{pg}, 50 \mathrm{pg}$, and 5 $\mathrm{pg}$, respectively.

${ }^{\mathrm{i}}$ Single tests. also varied among the insect extracts but not as dramatically as DNA from the symptomatic potato plants. Detection of phytoplasma DNA in beet leafhoppers by real-time PCR and nested PCR results on the same samples were nearly always in agreement. In only one case did a sample (single leafhopper sample 14) give a positive nested PCR result and fail to produce a real-time PCR signal. Generally, realtime PCR quantity estimates of about 0.1 ng or greater produced a positive nested PCR result (Tables 2 and 3).

Many researchers have reported the use of nested PCR for detection of phytoplasmas $(16,19,22,32)$. Although nested PCR may increase sensitivity, it also greatly increases the chance for contamination, leading to false-positive results, since the first-round reaction vessel must be opened, an aliquot removed, diluted, and used in the second reaction. Reaction components, the number of tubes necessary, and labor are also increased in the nested PCR procedure compared with the real-time PCR method. A third advantage of the real-time PCR method over nested PCR is elimination of the need for gel electrophoresis of the PCR products.

To our knowledge, this is the first report of real-time PCR detection of phytoplasmas in infected tomatoes, potatoes, and beet leafhopper vectors. The procedure detected phytoplasmas in diverse phytoplasma groups (16SrI, VI, and IX) and thus may be suitable for "broad spectrum" phytoplasma detection. For example, this technique could be used for detection of AY phytoplasma in Macrosteles spp. vectors. Similarly, Christensen et al. (7) reported real-time PCR detection of diverse groups of phytoplasmas in infected periwinkles, including lucerne virescence, a member of group 16SrVI, using real-time PCR.

In tests conducted here, the concentration of phytoplasma varied greatly among purple top-symptomatic potato plants and beet leafhopper vectors. Similarly, by using competitive PCR, Berges et al. (3) reported that the concentration of aster yellows phytoplasma varied considerably among host plants. In real-time PCR experiments reported recently (20), the concentration of apple proliferation phytoplasma in different plants and the psyllid vector were found to vary by up to five orders of magnitude.

The ability to detect phytoplasmas in individual leafhopper vectors can aid in the identification of potential vector species $(4,9,24)$. Additionally, the direct detection of phytoplasmas in vector insects may be a better predictor of possible disease problems than the insect population density alone (15). Detection of a pathogen within an insect, however, does not prove it is a vector, as was shown by Vega et al. (44). Previously, (9) PCR was used to demonstrate that of 15 leafhopper taxa tested, BLTVA was detected in only two, $C$. tenel- 
lus and less frequently in Ceratagallia spp. The nested PCR and real-time PCR tests of individual beet leafhoppers in this study indicated that $30 \%$ of the vectors contained detectable phytoplasma. This is approximately twice the percentage of phytoplasma-positive individual $C$. tenellus reported earlier (9). Goodwin et al. (15) reported the detection of aster yellows phytoplasma in up to $29 \%$ of individual aster leafhoppers collected at some locations. In contrast, Hill and Sinclair (17) detected phytoplasmas associated with ash yellows in only about $2 \%$ of potential leafhopper vectors.

Use of the real-time PCR methodology described herein, compared with the more commonly used nested PCR, will facilitate the testing of numerous insects collected from a commercial field setting and can rapidly determine whether or not they carry phytoplasma and therefore pose a threat to crop plants.

\section{LITERATURE CITED}

1. Altschul, S. F., Madden, T. L., Schaffer, A. A., Zhang, J., Zhang, Z., Miller, W., and Lipman, D. J. 1997. Gapped BLAST and PSI-BLAST: A new generation of protein database search programs. Nucleic Acids Res. 25:3389-3402.

2. Baric, S., and Dalla-Via, J. 2004. A new approach to apple proliferation detections: A highly sensitive real-time PCR assay. J. Microbiol. Methods 57:135-145.

3. Berges, R., Rott, M., and Seemüller, E. 2000. Range of phytoplasma concentrations in various plant hosts as determined by competitive polymerase chain reaction. Phytopathology 90:1145-1152.

4. Blomquist, C. L., and Kirkpatrick, B. C. 2002. Identification of phytoplasma taxa and insect vectors of peach yellow leaf roll disease in California. Plant Dis. 86:759-763.

5. Bosco, D., Palermo, S., Mason, G., Tedeschi, R., Marzachi, C., and Boccardo, G. 2002. DNA-based methods for the detection and the identification of phytoplasmas in insect vector extracts. Mol. Biotechnol. 22:9-18.

6. Bové, J. M., and Garnier, M. 2002. Phloemand xylem-restricted plant pathogenic bacteria. Plant Sci. 163:1083-1098.

7. Christensen, N. M., Nicolaisen, M., Hansen, M., and Schulz, A. 2004. Distribution of phytoplasmas in infected plants as revealed by real-time PCR and bioimaging. Mol. PlantMicrobe Interact. 17:1175-1184.

8. Clark, M. F., Morton, A., and Buss, S. L. 1989. Preparation of MLO immunogens from plants and a comparison of polyclonal and monoclonal antibodies made against primula yellows MLO-associated antigens. Ann. Appl. Biol. 114:111-124

9. Crosslin, J. M., Munyaneza, J. E., Jensen, A., and Hamm, P. B. 2005. Association of beet leafhopper (Hemiptera: Cicadellidae) with a clover proliferation group phytoplasma in Columbia basin of Washington and Oregon. J. Econ. Entomol. 98:279-283.

10. Daire, X., Boudon-Padieu, E., Berville, A., Schneider, B., and Caudwell, A. 1992. Cloned DNA probes for detection of grapevine flavescence dorée mycoplasma-like organism (MLO). Ann. Appl. Biol. 121:95-103.

11. Davies, D. L., and Clark, M. F. 1992. Production and characterization of polyclonal and monoclonal antibodies against peach yellow leafroll MLO-associated antigens. Acta Hortic. 383:275-283.

12. Davis, R. E., and Sinclair, W. A. 1998. Phytoplasma identity and disease etiology. Phytopa- thology 88:1372-1376.

13. Deng, S., and Hiruki, C. 1991. Genetic relatedness between two nonculturable mycoplasmalike organisms revealed by nucleic acid hybridization and polymerase chain reaction. Phytopathology 81:1475-1479.

14. Golino, D. A., Oldfield, G. N., and Gumpf, D. J. 1989. Experimental hosts of the beet leafhopper-transmitted virescence agent. Plant Dis. 73:850-854.

15. Goodwin, P. H., Mahuku, G. S., Liu, H., and Xue, B. G. 1999. Monitoring phytoplasma in populations of aster leafhoppers from lettuce fields using the polymerase chain reaction. Crop Prot. 18:91-99.

16. Gundersen, D. E., and Lee, I.-M. 1996. Ultrasensitive detection of phytoplasmas by nestedPCR assays using two universal primer pairs. Phytopathol. Mediterr. 35:144-151.

17. Hill, G. T., and Sinclair, W. A. 2000. Taxa of leafhoppers carrying phytoplasmas at sites of ash yellows occurrence in New York State. Plant Dis. 84:134-138.

18. Hiruki, C., and Wang, K. 2004. Clover proliferation phytoplasma: 'Candidatus Phytoplasma trifolii'. Int. J. Syst. Evol. Microbiol. 54:1349-1353.

19. Jacobs, K. A., Lee, I.-M., Griffiths, H. M., Miller, F. D., Jr., and Bottner, K. D. 2003. A new member of the clover proliferation phytoplasma group (16SrVI) associated with elm yellows in Illinois. Plant Dis. 87:241-246.

20. Jarausch, W., Peccerella, T., Schwind, N., Jarausch, B., and Krczal, G. 2004. Establishment of a quantitative real-time PCR assay for the quantification of apple proliferation phytoplasmas in plants and insects. Acta Hortic. (ISHS) 657:415-420.

21. Jung, H.-Y., Hamh, Y. I., Lee, J.-T., Hibi, T., and Namba, S. 2003. Characterization of a phytoplasma associated with witches' broom disease of potatoes in Korea. J. Gen. Plant Pathol. 69:87-89.

22. Khadhair, A.-H., Hiruki, C., and Hwang, S. F. 1997. Molecular detection of alfalfa witches'broom phytoplasma in four leafhopper species associated with infected alfalfa plants. Microbiol. Res. 152:269-275.

23. Khadhair, A.-H., Hiruki, C., Hwang, S. F., and Wang, K. 1997. Molecular identification and relatedness of potato witches'-broom phytoplasma isolates from four potato cultivars. Microbiol. Res. 152:281-286.

24. Klein, M., Weintraub, P. G., Davidovich, M., Kuznetsova, L., Zahavi, T., Ashanova, A., Orenstein, S., and Tanne, E. 2001. Monitoring phytoplasma-bearing leafhoppers/planthoppers in vineyards in the Golan Heights, Israel. J. Appl. Entomol. 125:19-23.

25. Lee, I.-M., Bottner, K. D., Miklas, P. N., and Pastor-Corrales, M. A. 2004. Clover proliferation group (16SrVI) subgroup A (16SrVI-A) phytoplasma is a probable causal agent of dry bean phyllody disease in Washington. Plant Dis. 88:429.

26. Lee I.-M., Bottner, K. D., Munyaneza, J. E., Secor, G. A., and Gudmestad, N. C. 2004. Clover proliferation group (16SrVI) Subgroup A (16SrVI-A) phytoplasma is a probable causal agent of potato purple top disease in Washington and Oregon. Plant Dis. 88:429.

27. Lee, I.-M., Davis, R. E., and Hiruki, C. 1991. Genetic interrelatedness among clover proliferation mycoplasmalike organisms (MLOs) and other MLOs investigated by nucleic acid hybridization and restriction fragment length polymorphism analyses. Appl. Environ. Microbiol. 57:3565-3569.

28. Lee, I.-M., Davis, R. E., Sinclair, W. A., DeWitt, N. D., and Conti, M. 1993. Genetic relatedness of mycoplasmalike organisms detected in Ulmus spp. in the United States and Italy by means of DNA probes and polymerase chain reactions. Phytopathology 83:829-833.
29. Lee, I.-M., Gundersen-Rindal, D. E., and Bertaccini, A. 1998. Phytoplasma: Ecology and genomic diversity. Phytopathology 88:1359-1366.

30. Lee, I.-M., Gundersen-Rindal, D. E., Davis, R. E., and Bartoszyk, I. M. 1998. Revised classification scheme of phytoplasmas based on RFLP analyses of 16S rRNA and ribosomal protein gene sequences. Int. J. Syst. Bacteriol. 48:1153-1169.

31. Lee, I.-M., Hammond, R. W., Davis, R. E., and Gundersen, D. E. 1993. Universal amplification and analysis of pathogen 16S rDNA for classification and identification of mycoplasmalike organisms. Phytopathology 83:834-842.

32. Leyva-López, N. E., Ochoa-Sánchez, J. C., Leal-Klevezas, D. S., and Martínez-Soriano, J. P. 2002. Multiple phytoplasmas associated with potato diseases in Mexico. Can. J. Microbiol. 48:1062-1068.

33. Liao, X.-L., Xhu, X.-L., Chen, H.-Y., Huang, W.-S., Luo, K., Zhao, W. J., Ma, R.-Q., and Zhu, J. Y. 2002. Establishment of real-time fluorescent PCR method with TaqMan probe for phytoplasma detection and identification. Acta Phytopathol. Sin. 32:361-367.

34. Lorenz, K.-H., Schneider, B., Ahrens, U., and Seemüller, E. 1995. Detection of the apple proliferation and pear decline phytoplasmas by PCR amplification of ribosomal and nonribosomal DNA. Phytopathology 85:771-776.

35. Oldfield, G. N., Kaloostian, G. H., Pierce, H. D., Granett, A. L., and Calavan, E. C. 1977. Beet leafhopper transmits virescence to periwinkle. Calif. Agric. 31(6):14-15.

36. Presting, G. G., Smith, O. P., and Brown, C. R. 1995. Resistance to potato leafroll virus in potato plants transformed with the coat protein gene or with vector control constructs. Phytopathology 85:436-442.

37. Sambrook, J., Fritsch, E. F., and Maniatis, T. 1989. Molecular Cloning: A Laboratory Manual. 2nd ed. Cold Spring Harbor Laboratory, Cold Spring Harbor, NY.

38. Schneider, B., Seemüller, E., Smart, C. D., and Kirkpatrick, B. C. 1995. Phylogenetic classification of plant pathogenic mycoplasma-like organisms or phytoplasmas. Pages 369-380 in Molecular and Diagnostic Procedures in Mycoplasmology. Vol. 1. S. Razin and J. G. Tully, eds. Academic Press, San Diego, CA.

39. Schultz, T. R., and Shaw, M. E. 1991. Occurrence of the beet leafhopper-transmitted virescence agent in red and daikon radish seed plants in Washington State. Plant Dis. 75:751.

40. Shaw, M. E., Golino, D. A., and Kirkpatrick, B. C. 1990. Infection of radish in Idaho by beet leafhopper transmitted virescence agent. Plant Dis. 74:252

41. Shaw, M. E., Kirkpatrick, B. C., and Golino, D. A. 1993. The beet leafhopper-transmitted virescence agent causes tomato big bud disease in California. Plant Dis. 77:290-295.

42. Smart, C. D., Schneider, B., Blomquist, C. L. Guerra, L. J., Harrison, N. A., Ahrens, U., Lorenz, K.-H., Seemüller, E., and Kirkpatrick, B. C. 1996. Phytoplasma-specific PCR primers based on sequences of the 16S-23S rRNA spacer region. Appl. Environ. Microbiol. 62:2988-2993.

43. Smart, C. D., Thomson, S. V., Flint, K., and Kirkpatrick, B. C. 1993. The beet leafhopper transmitted virescence agent is associated with diseased potatoes in Utah. (Abstr.) Phytopathology 83:1399.

44. Vega, F. E., Davis, R. E., Barbosa, P., Dally, E. L., Purcell, A. H., and Lee, I.-M. 1993. Detection of a plant pathogen in a nonvector insect species by the polymerase chain reaction. Phytopathology 83:621-624.

45. Zhang, Y.-P., Uyemoto, J. K., and Kirkpatrick, B. C. 1998. A small-scale procedure for extracting nucleic acids from woody plants infected with various phytopathogens for PCR assay. J. Virol. Methods 71:45-50. 
On August 20, 2007, this article was changed on page 665, column 3, in the RESULTS AND DISCUSSION section. The first sentence in the section, which starts in column 2 , correctly reads "The real-time PCR assay reliably detected the group 16SrVI phytoplasma in DNA from infected tomatoes, potatoes, and the aster yellows (group 16SrI) and pigeon pea witches'-broom (group 16SrIX) phytoplasma-infected periwinkles (Table 2)." 